\title{
THE IMPACT OF COLLABORATIVE WRITING STRATEGY AT STUDENTS' WRITING SKILL IN DESCRIPTIVE TEXT
}

\author{
Saeful Arifin and Choiril Anwar \\ Sultan Agung Islamic University, Indonesia
}

\begin{abstract}
The aim of this study was to find out whether or not collaborative writing strategy is effective to improve students' writing skill in descriptive text when they were applied to the tenth grade students of SMA N 1 Karangtengah in academic year of 2015/2016. The collaborative writing strategy was the independent variable, while students' writing skill in descriptive text was the dependent variable. Quasi experimental research design was used in this study. The population of this study was the tenth graders of SMA N 1 Karangtengah in the academic year of 2015/2016 which the total number of students was 340. The sample of this study consisted of X MIA 3 as an experimental class and X MIA 4 as a control group. The technique used in collecting the data was test. The finding of the study showed that the pre-test mean score of experimental group was 69.38 and control group was 68.71. After being given treatment for four meetings, it was found that the mean scores of experimental group was 82.15 and control group was 76.32 . The result of the analysis showed that there was a significant difference between the mean score of pre-test and post-test. It was supported by t-test result in which the significant difference in the result of post-test between experimental and control group was $0.000(<$ 0.05 ). It means that $\mathrm{H}_{0}$ was rejected and $\mathrm{H}_{a}$ was accepted. Therefore, it could be concluded that collaborative writing strategy were effective to improve students's writing skill in descriptive text.
\end{abstract}

Key words: collaborative writing strategy, writing skill, and descriptive text.

\section{INTRODUCTION}

English is very significant. Regarding the importance of the English language, our government has drawn up English as a foreign language that should be mastered by the students. In Indonesia, English teaching aims at mastering four basic skills of language, which include listening, speaking, reading, and writing skills. English language is one of the foreign languages to be taught at school. As an international language, English is taught to the students from junior high school up to university.

It is certainly that the students of senior high school still find some difficulties. They still get confused in mastering English language because learning English language is different from learning local language. As we know, English has an important role in international relationship in which it is used in many countries in the world.

Writing skill is one of skills that produces an output like a text, news item and report. In fact, most of the teachers often ignore this skill because of many reasons. Moreover, in learning writing skills, most of the teachers still focus on the product rather than the process. In learning writing skill in descriptive text, the students have to master vocabulary and know how to use grammar in making 
texts or sentences. It is an important skill because it will be applied in many aspects of life. Through writing, people are supposed to be able to express their ideas in writing form. There are many ways to express writing and one of them is through a text. According to Hyland (2002), writing is learned, rather than taught, and the teacher's best method are flexibility and support.

There are many text types taught in senior high school. Each text has different social function, schematic structures, and language features. One of the texts taught for the tenth grade students of senior high school is descriptive text.

At SMA N 1 Karangtengah, it is clearly stated that one of the objectives of the English subject is developing the four basic abilities. In fact, the students of this school were good in writing essay in Bahasa but not in English language. They still had difficulty in arranging words in the text and selection words. At the same time, the teacher was confused for using a method. The evidence was with the result of the test that there was out of 40 students, $75 \%$ of them (around 30 students) got under 60. The result indicates that the students were weak to make an essay in English language.

The preliminary study started when the first writer did teacher training (PPL) in SMA N 1 Karangtengah. When doing preliminary observation, the writer found that students had weakness at making an essay about writing descriptive text. The writers chose this school as the object of the research was for some following considerations: first, as it is stated above that the students had problems in their English writing. Second, this school needed to improve the students' quality in writing generally.

From this problems, the writers think one of the alternative strategies to improve student's writing skill in descriptive text especially in SMA $N 1$ Karangtengah is to apply collaborative writing strategy as the solution because this strategy has not been taught intensively in this school.

Storch (2011) argues, "Collaborative writing strategy is the joint production of a text by two or more writers." Despite the widespread use of collaborative writing in the world outside the second language (L2) classroom, the use of collaborative writing tasks in L2 classes, to date, seems relatively limited. The entire collaborative process can have the end result of producing writers who are more independent, "as they have attained the skills necessary to self-edit and revise their own writing" (Rollinson, 2005, p. 29). It can be inferred from the above that through collaborative writing, students can learn multiple language skills more effectively than by working alone.

Therefore, the writers will then try to investigate the effectiveness of collaborative writing strategy to improve student's writing skill in descriptive text, the students are tenth graders of SMA N 1 Karangtengah.

The objective of the study is to find out whether the use of collaborative writing strategy effective to improve students' writing skill in descriptive text of the tenth graders in SMA N 1 Karangtengah in the academic year of 2015/2016.

\section{COLLABORATIVE WRITING STRATEGY}

The writers will present the definition of collaborative writing strategy as explained in the background of study beforehand. Storch (2011, p. 275) argues, 
"Collaborative writing strategy is the joint production of a text by two or more writers." While Rollison says that the entire collaborative process can have the end result of producing writers who are more independent, as they have attained the skills necessary to self-edit and revise their own writing (2005). It can be inferred from the above that through collaborative writing, students can learn multiple language skills more effectively than by working alone.

\section{Writing Skills}

Jim (2010) explained that writing skill is complex and difficult to learn. Requiring mastery is not only grammatical patterns but also the rule of writing such as high degree of organization in the development of ideas and information and also choosing the appropriate vocabularies and sentence structure to create a style which is appropriate to subject matter.

Based on definition above, it can be concluded then that writing skill is specific abilities which help writers put their thought in to words in meaningful form and mentally interact with the message. It has purpose not only for media but also giving information. Everyday many people do writing activity by using mobile phone to sending a message. It functions to give information. Writing can be said to be act of forming symbols. When we write, we use graphic symbols.

\section{Descriptive Text}

Descriptive text is a kind of text with a purpose to give information. The context of this kind of text is the description of particular thing, animal, person, or others, for instance: our pets or a person we know well. Descriptive text is a text which is created when the words are put together to communicate a message.

\section{METHODS}

In this study, the writers used quantitative approach. Babbie (2010) argued that quantitative analysis is the numerical representation and manipulation of observations for the purpose of describing and explaining the phenomena that those observations reflect. The writers used one of quantitative method types, namely quasi experimental design which includes pre-test, treatments and posttest. According to Sugiyono (2009), the quasi experimental design is a study which is aimed at discovering the influence of particular treatment. This design covers quantitative data and statistical technique in analyzing data. The writers used quasi-experimental design which applies collaborative writing strategy as method to improve students' writing skill in descriptive text.

The classes that will be used in the research were divided into two groups. One of them got a treatment and one did not. The assignment of students into the groups was not based on randomization technique, because quasi-experimental design does not have the true characteristics like randomization.

The research design of the experiment can be described as below:

\begin{tabular}{lccc}
\hline $\mathrm{E}$ & $\mathrm{O}_{1}$ & $\mathrm{X}$ & $\mathrm{O}_{4}$ \\
$-\mathrm{C}$ & $\mathrm{O}_{3}$ & $\cdots$ & $\mathrm{O}_{4}$ \\
\hline
\end{tabular}

(Arikunto, 2006, p. 86) 


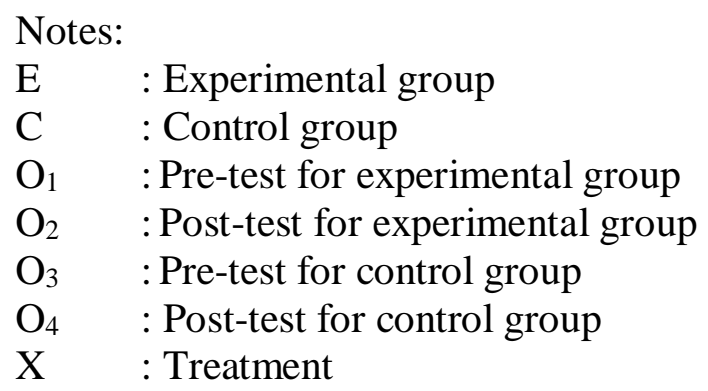

\section{Subject of the Study}

According to Arikunto (2010, p. 173), "Population is the total numbers of research subject." The writers chose the students of tenth graders of SMA N 1 Karangtengah as population. There are nine classes, and each class is around 38 students. Then, the total member of students in this population was 340 students. The way of choosing sample is called sampling technique. In this research, the writers used convenience sampling. Convenience or opportunity sampling is the most common type of sampling in L2 studies where the only criterion according to Dörnyei (2007), is the convenience of the writers. The reason why the writers used this sampling technique because the English teacher ordered to use X MIA 3 and X MIA 4 as sample. According to the Arikunto (2006, p. 134), "If the subjects are fewer than 100 people, it is better for the writers to take all of the population as a sample."

This research used two classes. First is X MIA 3, with 39 students, chosen as experimental class, and another class is X MIA 4, with 38 students, chosen as control class.

\section{Instrument of the Study}

"Instrument is a device to measure in certain method when conducting research" (Arikunto, 2006, p. 149). In this research, writing descriptive test used as an instrument to measure the student's writing achievement. This writing test would be given to each class, experimental class and control class. Furthermore, in order to know the students' writing achievement this writing test was used in pre-test. After the treatment given, writing descriptive text also was used as posttest to identify the sudents' writing achievement.

\section{DISCUSSION}

The research was designed to find out whether collaborative writing strategy could help students to improve their writing skill or not. In order to support this research, the test was used to get the data. The feature of SPSS 16.0 software was used to analyze the data in order to find out the significant difference between pretest and post-test in the experimental class also pre-test and post-test in control class. There were three acivities in this study: pre-test, treatment, and post-test. 


\section{Data Collection of Pre-Test}

The aim of pre-test is to know the ability of students before they get treatments. In the experimental group and control group,the pretest was done on April $27^{\text {th }} 2016$. Every student was asked to describe a picture with a descriptive text to know their writing ability. It took 60 minutes.

Table 1 Pre-test Result

\begin{tabular}{|c|c|c|c|c|}
\hline \multicolumn{5}{|c|}{ One-Sample Statistics } \\
\hline & $\mathrm{N}$ & Mean & Std. Deviation & $\begin{array}{l}\text { Std. Error } \\
\text { Mean }\end{array}$ \\
\hline Experimental & 39 & 69.38 & 3.850 & .616 \\
\hline Control & 38 & 68.71 & 4.678 & .759 \\
\hline
\end{tabular}

The result of pre-test showed that the means of experimental and control groups are 69.38 and 68.71. It means that the both of experimental and control group have average mean score.

\section{Normality}

After getting the pre-test result of experimental and control group, the writers analyzed the normality of the data. The writers used One-Sample Kolmogorov-Smirnov Test to know the standard normality of the groups. It can be shown in the table of normality test.

Table 2. The Result of Normality Test

\begin{tabular}{llrr}
\hline \multicolumn{4}{c}{ One-Sample Kolmogorov-Smirnov Test } \\
\hline & & Experimental & Control \\
\hline $\mathrm{N}$ & 39 & 38 \\
\hline Normal Parameters $^{\mathrm{a}}$ & Mean & 69.38 & 68.71 \\
\cline { 2 - 4 } & Std. Deviation & 3.850 & 4.678 \\
\hline Most Extreme & Absolute & .144 & .193 \\
\cline { 2 - 4 } Differences & Positive & .144 & .193 \\
\cline { 2 - 4 } & Negative & -.136 & -.127 \\
\hline Kolmogorov-Smirnov Z & .897 & 1.187 \\
\hline Asymp. Sig. (2-tailed) & & .397 & .120 \\
\hline a. Test distribution is Normal. & & \\
\hline
\end{tabular}

The table showed that the data of experimental group was normal because the sig. $(2$-tailed $)=0.397(\mathrm{p}>0.05)$ and the data of control group showed that the sig. $(2$-tailed $)=0.120(\mathrm{p}>0.05)$.

\section{Homegeneity}


After the data were normal, for showing homogeneity the writers used Levene test as below:

Table 3 The Result of Homogeneity Test

\begin{tabular}{ccccc}
\hline \multicolumn{5}{c}{ Test of Homogeneity of Variances } \\
\hline $\begin{array}{c}\text { Levene } \\
\text { Statistic }\end{array}$ & df1 & & df2 & Sig. \\
\hline 1.445 & 7 & 24 & .234 \\
\hline
\end{tabular}

The result of Levene test showed that Sig. score was $0.234>0.05$. It could be concluded that students' condition before the treatments were homogeneous. It is shown on the table 3 above After the data were normal and homogeneous, the writers applied t-test.

T-Test as below:

For answering the hypotheses, the writers used independent sample t-test Table 4 The Result of T-Test

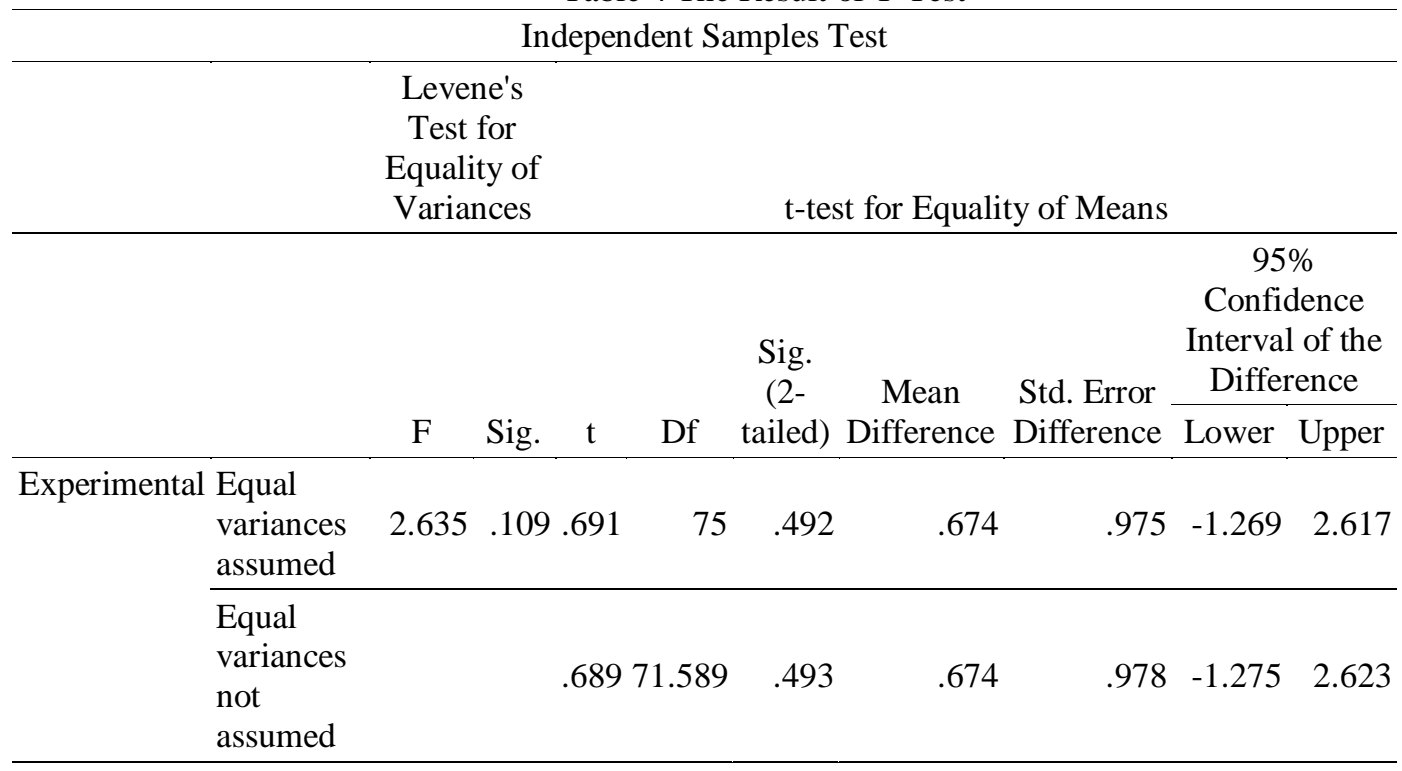

The result of independent sample t-test for pre-test showed that t-value was obtained 0.691. Sig. (2-tailed) was obtained 0.492, and for the 95\% Confidence Interval of the Difference was obtained -1.269 for the lower interval and 2.617 for the upper interval. The numbers of subjects in this study for both the experimental and control groups was 77 with the degree of freedom $(\mathrm{df})=75$. While the t-value was 0.691 and t-table was 2.000 , so t-value was lower than t-table $(0.691<2.000)$. 
In addition, the independent sample t-test showed that Sig. (2.tailed) was 0.492 (> 0.05), for t-test result if t-value < t-table and Sig. $>0,05$. It could be concluded that $\mathrm{H}_{a}$ was rejected and $\mathrm{H}_{0}$ was accepted, hence there was no a significant difference on students' writing score between control and experimental group in pre-test.

\section{Data Collection of Post-test}

At the end of study, the writers gave post-test to the students. The test was writing descriptive text. The purpose of this test was to know there was a significant difference in students writing skill between who were getting treatment and those who were not. In the experimental group and control group, it was done on May $4^{\text {th }} 2016$ in XMIA3 class and X MIA 4 class. The activity in post-test was the same as the pre-test, where every student was asked to describe a picture with a descriptive text to know their writing ability. It took 60 minutes.

Table 5. The Result of Post-Test

\begin{tabular}{|c|c|c|c|c|}
\hline \multicolumn{5}{|c|}{ One-Sample Statistics } \\
\hline & $\mathrm{N}$ & Mean & Std. Deviation & $\begin{array}{l}\text { Std. Error } \\
\text { Mean }\end{array}$ \\
\hline Experimental & 39 & 82.15 & 6.934 & 1.110 \\
\hline Control & 38 & 76.32 & 6.502 & 1.055 \\
\hline
\end{tabular}

The result of Group Statistic showed that the means of experimental and control groups are 82.15 and 76.32. It means that the both of experimental and control group have average mean score. below:

For answering the hypotheses, the writers used independent sample t-test as

Table 6 The Result of T-Test of Post-test Independent Samples Test

\begin{tabular}{|c|c|c|c|c|c|c|c|c|c|}
\hline & $\begin{array}{r}\text { Leve } \\
\text { Test } \\
\text { Equal } \\
\text { Varia }\end{array}$ & $\begin{array}{l}\text { ne's } \\
\text { for } \\
\text { ity of } \\
\text { nces }\end{array}$ & & & t-tes & st for Equali & ty of Means & & \\
\hline & & & & & $\begin{array}{l}\text { Sig. } \\
(2-\end{array}$ & Mean & Std. Error & $\begin{array}{r}95 \% \text { Cor } \\
\text { Interval } \\
\text { Differ }\end{array}$ & $\begin{array}{l}\text { fidence } \\
\text { of the } \\
\text { ence }\end{array}$ \\
\hline & $\mathrm{F}$ & Sig. & $\mathrm{T}$ & Df & tailed) & Difference & Difference & Lower & Upper \\
\hline $\begin{array}{c}\text { Posttest Equal } \\
\text { variances } \\
\text { assumed }\end{array}$ & .279 & .599 & 3.809 & 75 & .000 & 5.838 & 1.533 & 2.785 & 8.891 \\
\hline $\begin{array}{l}\text { Equal } \\
\text { variances } \\
\text { not } \\
\text { assumed }\end{array}$ & & & \multicolumn{2}{|c|}{3.81274 .892} & .000 & 5.838 & 1.531 & 2.787 & 8.889 \\
\hline
\end{tabular}

The result of independent sample t-test for post-test showed that t-value was obtained 3.809.Sig. (2-tailed) was obtained 0.000 , and for the $95 \%$ Confidence Interval of the Difference was obtained 2.785 for the lower interval 
and 8.891 for the upper interval. The numbers of subjects in this study for both the experimental and control groups was 77 with the degree of freedom (df) $=75$. While the obtained t-value was 3.809 and t-table was 2.000, so t-value was higher than t-table $(0.611<2.000)$.

In addition, the independent sample t-test showed that Sig. (2.tailed) showed 0.000, for t-test result if $\mathrm{t}$-value $>\mathrm{t}$-table and Sig. $<0,05$. It means that $\mathrm{H}_{\mathrm{o}}$ is rejected and $\mathrm{H}_{\mathrm{a}}$ is accepted. It could be concluded that there was a significant difference on students' writing score between control and experimental group in post-test.

\section{CONCLUSION}

Based on the explanations above, it can be assumed that using collaborative writing strategy can improve the students' writing skill in descriptive text to tenth graders of SMA N 1 Karangtengah. As the result, in the pre - test, the mean score of the experimental and the control group were 69.38 and 68.71, and the mean score of post - test of the experimental group and the control group, those were 82.15 and 76.32. It means that collaborative writing strategy may be considered as a technique to improve students' writing skill in descriptive text.

\section{SUGGESTIONS}

There are some suggestions offered from this study for teacher and students. They are stated as follows: Teachers should consider that writing skill is not about diction, and structure. Content is also an important factor in writing skill. Students have to practice to write more and more, in order to improve their writing ability. Furthermore, students should use collaborative writing strategy if they get difficulties when write an English text, they must learn together with their friends and discuss about the difficulties of writing text. The last but not least, the writers hope that any benefits of this study can be useful for improving students' writing skill. Thus, any information which is given in this research, is supposed to be a reference for other writers for any related study.

\section{REFERENCES}

Arikunto, S. (2006). Prosedur penelitian: Suatu pendekatan praktek. Jakarta: PT Rineka Cipta.

Arikunto, S. (2010). Prosedur penelitian: Suatu pendekatan praktek. Jakarta: PT Rineka Cipta.

Babbie, E. R. (2010). The practice of social research. Belmont: CA: Wadsworth Cengage.

Dörnyei, Z. (2007). Research methods in applied linguistic. Oxford: Oxfrod University Press.

Jim, A. (2010). Writing skill in second language. New York: Pearson Education.

Rollinson, P. (2005). Using peer feedback in the ESL writing class. ELT Journal. 
Stroch, N. (2011). Annual review of applied linguistic. Cambridge: Cambridge University Press.

Sugiyono. (2009). Metode penelitian kuantitatif dan kualitatif. Bandung: CV. Alfabeta. 